\title{
Synthesis and Characterization of Polyesters from Glycerol by-Product of Biodiesel Production
}

\author{
Carla V. Rodarte de Moura, * Antonia S. L. Nunes, Jose M. Moita Neto, \\ Haroldo L. S. Neres, Lee M. G. de Carvalho and Edmilson M. de Moura
}

Departamento de Química, Universidade Federal do Piauí, 64049-550 Teresina-PI, Brazil

\begin{abstract}
Glicerol, um sub-produto da produção de biodiesel, pode reagir com ácidos di-carboxílicos, resultando em poliésteres, e ser usado na composição de resinas do tipo uréia/formaldeído ou fenol/formaldeído para melhorar as qualidades de aderência e resistência à umidade dessas resinas. Neste trabalho, foram sintetizados seis tipos de resinas derivadas do glicerol, sendo nomeadas GAA (glicerol/ácido adípico), GAAU (glicerol/ácido adípico/uréia), GAF (glicerol/ácido ftálico), GU (glicerol/uréia), GUF (glicerol/uréia/formaldeído) e GF (glicerol/formaldeído). As resinas derivadas dos ácidos carboxílicos tiveram melhor estabilidade térmica (até $350{ }^{\circ} \mathrm{C}$ ) do que as resinas derivadas do formaldeído (até $200^{\circ} \mathrm{C}$ ). As massas moleculares médias das resinas foram determinadas por espectrometria de massas por tempo de vôo acoplada à ionização dessortiva de matriz por laser (MALDI-TOF MS) e cromatografia de permeação em gel (GPC), e encontram-se na faixa de 1800-2800 Da, sendo portanto, oligômeros, e os índices de polidispersão no intervalo de 1,3 a 1,8. As técnicas de ressonância magnética nuclear (NMR) de ${ }^{1} \mathrm{H}^{13} \mathrm{C}$ foram usadas para identificar as estruturas das resinas.
\end{abstract}

Glycerol, a by-product from biodiesel production can react with di-carboxylic organic acids, resulting in polyesters, and can be used in the composition of urea/formaldehyde or phenol/ formaldehyde resins to improve the qualities of adhesion and moisture resistance of them. In this work, six kinds of resins derived from glycerol, named as GAA (glycerol/adipic acid), GAAU (glycerol/adipic acid/urea), GAF (glycerol/phtalic acid), GU (glycerol/urea), GUF (glycerol/ urea/formaldehyde) and GF (glycerol/formaldehyde), were synthesized. The resins derived from carboxylic acids had better thermal stability (up to $350^{\circ} \mathrm{C}$ ) than those derived from formaldehyde (up to $200^{\circ} \mathrm{C}$ ). The average molecular weights of the resins were determined by matrix assisted laser desorption ionization time-of-flight mass spectrometry (MALDI-TOF MS) and gelpermeation chromatography (GPC), and are in the range of 1800-2800 Da, being oligomers, and the polydispersity indexes are in the range of 1.3 to 1.8 . The ${ }^{1} \mathrm{H}$ and ${ }^{13} \mathrm{C}$ nuclear magnetic resonance (NMR) techniques were used to identify the structure of the resins.

Keywrods: glycerol, resins, biodiesel

\section{Introduction}

The prospect of shortages and the damage, which is causing the pretroleum to the environment, has contributed to the new emerging areas of interest and research opportunities, based on the use of biomass because of its renewable nature, availability, biodegradability and low cost..$^{1-3}$ Questions about renewable resources, which may replace, at least in part, the fossil fuels, climate change and energy security coupled with sustainable development, have been discussed all over the world to minimize the effects of global warming. ${ }^{4.5}$

*e-mail: carla@ufpi.edu.br
Renewable fuels are very promising alternatives to replace the petroleum, especially biodiesel, which can be obtained by the transesterification of vegetable oils or animal fats. This reaction produces alkyl esters and glycerin, that is the most important by-product of biodiesel production. ${ }^{6}$ Transesterification of vegetable oils generate about $10 \mathrm{~m}^{3}$ of glycerin for every $90 \mathrm{~m}^{3}$ of biodiesel produced, and approximately $200,000 \mathrm{~m}^{3}$ per year are estimated to be produced only in Brazil by 2013. ${ }^{4}$ According to Gonçalves et al. ${ }^{7}$, these values are very high for consumption in the Brazilian market of approximately $35,000 \mathrm{~m}^{3}$ per year. According Zhou et al. ${ }^{8}$ the market of glycerin is very limited and any increase in biodiesel production will cause 
a sharp decline of over $60 \%$ of its value. The commercial viability of biodiesel is complicated because now the market has an absorption limit for growing supply of glycerin. It is necessary to find new applications for this product, ${ }^{9-11}$ and value added to glycerin generated, otherwise this by-product could undermine the economic viability of any production process of biodiesel as renewable fuel. .7

The utilization of glycerol as a chemical platform represents an opportunity to obtain value added products from a highly functionalized and cheap raw material, and much research has been recently dedicated to find new chemical pathway for the glycerol transformation to value added products.

Glycerol is a molecule used for production of polymers due to their polyfunctional reactivity. The glycerol polymers produced can have different applications, as polyols substitutes, polivinylic alcohol, lubricant, row materials to produce resins and polyurethanes. ${ }^{12}$ Glycerol can be a plasticizer agent when added to phenolic composite and can increase the elasticity and toughness of the phenolic materials. The presence of glycerol in the phenolic network reduces the characteristic brittleness of phenolic resins by decreasing to cross-link density of the cure composites. ${ }^{13}$ The glycerol can react with di-carboxylic organic acids, resulting in polyesters.

The esters derived from the phthalic acids have found many applications. For instance, poly(ethylene terephtalate) (PET) has excellent mechanical properties and is used for the manufacturing of plastic bottles for carbonated beverages (soft drinks, etc.). ${ }^{13}$ Poly(butylene therephtalate) (PBT) can be used for a wide range of applications, for example, for thin-walled injection-moulded parts in electrical engineering applications, for especially dimensionally stable components of high surface quality in the automotive industry, as a barrier layer in multilayer fuel lines, and in the cable industry. ${ }^{14}$ PBT is also used in plug-in connectors, connector strips, switching systems, housings for automatic cut-outs, capacitor pots, in coil formers, lamp parts, PC fans, power supply components, parts for electric drives, sheathing for waveguides and many other products and not least in vehicle electrical systems (ignition coil housing). ${ }^{14}$ The preparation of polyesters from multi-functional phenols and phthalic acid gave rise to production of gas separation membranes with good selectivity coefficients. ${ }^{15}$ Therefore, the production of polyesters from glycerol and phthalic acid should produce new materials for the preparation of desalination membranes and as modifiers for polyurethane foams.

Adhesives based on urea-formaldehyde (UF) are widely employed in the industries of wood panels. According to Roffael and Schneider, ${ }^{16}$ 90\% of plates crowded around the world are produced with the resin urea-formaldehyde.
However, this adhesive has very limited resistance to moisture. ${ }^{16}$

The polyols such as glycerol can be used in the composition of urea/formaldehyde or phenol/formaldehyde resins to improve the qualities of adhesion and moisture resistance of them. Therefore, this work aimed to synthesize resins based on glycerin, phtalic acid, adipic acid, urea and formaldehyde with the possibility of their application on the composite factory, mainly in the furniture sector.

\section{Experimental}

\section{Material and instrumentation}

The glycerol, urea and formaldehyde were 99.5 and $38 \%$ of purity and purchased by Vetec (Duque de Caxias-RJ, Brazil). The adipic and phytalic acid were purchased by Riedel-de Haen AG (Seelze, Hannover, Germany) with $99.5 \%$ of purity. All the reagents were used without further purification.

Fourier transform infrared (FTIR) analysis of resins was performed using a confocal microscope equipment Raman/FTIR. The spectra were obtained with resolution of $4 \mathrm{~cm}^{-1}$ and wavenumber between $4000-400 \mathrm{~cm}^{-1}$. Nuclear magnetic resonance (NMR) spectra were obtained using an INOVA-500 spectrometer at a resonance frequency of $500 \mathrm{MHz}$. DMSO- $d_{6}$ was used as solvent as well internal standard to run the spectra of resins. Thermogravimetric analysis (TGA) were obtained on TA Instruments equipment, model TGA 2050. The experiments were performed using a pan of aluminum, with mass ranging from 5.3 to $9.4 \mathrm{mg}$ under a nitrogen atmosphere with flow rate $150 \mathrm{~mL} \mathrm{~min}^{-1}$. The temperature range was $25-600{ }^{\circ} \mathrm{C}$ using a heating rate of $10{ }^{\circ} \mathrm{C} \mathrm{min}-1$. Differential scanning calorimetric (DSC) curves were obtained in equipment from TA Instruments, DSC 2920, the type of heat flow conducted in an $\mathrm{N}_{2}$ atmosphere, under a flow rate of $80 \mathrm{~mL}$ $\mathrm{min}^{-1}$. The range of temperature was $25-600{ }^{\circ} \mathrm{C}$ with a heating rate of $10{ }^{\circ} \mathrm{C} \mathrm{min}^{-1}$. The molecular weights of the resins were measured by gel-permeation chromatography (GPC) on a HP-1090M, equipped with a UV-diode array detector and a Viscotek differential viscosimeter detector, model 200 (SEC-DV). PS standards were used for the universal calibration. The solvent/eluent was THF, the flow rate was $1.0 \mathrm{~mL} \mathrm{~min}^{-1}$, and $4 \mathrm{PL}$-gel Mixed C columns were applied by matrix assisted laser desorption ionization time-of-flight mass spectrometer (MALDI-TOF MS) using the equipment Voyager-DE STR (Applied Biosystems, Foster City, CA) under optimized conditions in reflectance mode. MALDI was made by irradiating the sample with a laser of $337 \mathrm{~nm}\left(\mathrm{~N}_{2}\right)$ creep threshold. The samples were 
dissolved in methanol before injection in the equipment with a concentration of $1 \times 10^{-4} \mathrm{mmol} \mathrm{mL}^{-1}$.

\section{Synthesis of resins}

Six kinds of resins were synthesized based on glycerol (Table 1) according to methods adapted from the literature. . $^{14,17,18}$

Table 1. Molar ratio of resins and reaction time

\begin{tabular}{lcc}
\hline Resin & Molar ratio & Reaction time $/ \mathrm{h}$ \\
\hline GAA & $1: 1$ (glycerol/adipic acid & 2.5 \\
GAAU & $3: 2.5: 0.5$ (glycerol/adipic acid/urea) & 2.5 \\
GAF & $1: 1$ (glycerol/phtalic acid) & 2.5 \\
GU & $1: 2$ (glycerol/urea) & 2.5 \\
GUF & $1: 1: 1.8$ (glycerol/urea/formaldehyd) & 3 \\
GF & $1: 1.1$ (glycerol/formaldehyd) & 3 \\
\hline
\end{tabular}

The reagents with different molar ratios (Table 1) were added into a beaker, and heated to $160{ }^{\circ} \mathrm{C}$ under constant magnetic stirring. No substance was added as the function of catalyzing, initiating or terminating the reaction. After the reaction time, which ranged as shown in Table 1, the resins were collected and left in the oven for $2 \mathrm{~h}$ at $103 \pm 2{ }^{\circ} \mathrm{C}$ for evaporation of volatile residuals, and then cooled at room temperature.

\section{Results and Discussion}

The main absorptions bands in the infrared region of the resins synthesized in this study are shown in Table 2.

The esterification of glycerol with phthalic and adipic acids was confirmed by the presence of the bands 1732 , 1230, 1780 and $1250 \mathrm{~cm}^{-1}$. The absence of absorption at $1711 \mathrm{~cm}^{-1}$ (assigned to $-\mathrm{COOH}$ ) evidenced that the esterification reaction was almost complete for the poliesters derived from phtalic acid, adipic acid and urea.

Through the NMR spectra and the study described by Stumbo and Bruchmann, ${ }^{19}$ it was possible to propose structures of resins. Beside, the ChemBioDraw software were used to simulate the spectra of ${ }^{1} \mathrm{H}$ NMR. The simulate and the real ${ }^{1} \mathrm{H}$ NMR and ${ }^{13} \mathrm{C}$ NMR spectra of the resin GAF are shown in Figure 1.

${ }^{1} \mathrm{H}$ NMR of GAF resin showed chemical shifts at $\delta 3.29-4.90$ and 5.17, so they are attributed to displacement of first and third hydrogen and central hydrogen of glycerol molecule, respectively. The chemical shift of central hydrogen was observed in the spectrum of triacetin, ${ }^{20,21}$ and it was attributed to hydrogen connected to secondary carbon for glycerol carbonate. The same displacement was observed in simulate structures. The displacements at $\delta 7.65$
Table 2. Main absorption bands in the infrared region

\begin{tabular}{|c|c|c|}
\hline Sample & Wavenumber $/ \mathrm{cm}^{-1}$ & Assigments \\
\hline GAA & $\begin{array}{c}3460 \\
2960-2873 \\
1732 \\
1455 \\
1230 \\
1212\end{array}$ & $\begin{array}{c}v \mathrm{O}-\mathrm{H} \text { alcholic, carboxylic acid } \\
v \text { C-H alliphatic } \\
v \mathrm{C}=\mathrm{O} \text { (ester) } \\
\delta \mathrm{C}-\mathrm{H} \text { (methyl) } \\
v \mathrm{C}-\mathrm{O} \text { (ester) } \\
\delta \mathrm{C}-\mathrm{C} \text { (ester) }\end{array}$ \\
\hline GAAU & $\begin{array}{c}3440 \\
1778 \\
2974-2856 \\
1684 \\
1496 \\
1245 \\
1196 \\
\end{array}$ & $\begin{array}{c}v \mathrm{O}-\mathrm{H} \text { alcholic } \\
v \mathrm{C}=\mathrm{O} \text { (adipic acid) } \\
v \mathrm{C}-\mathrm{H} \text { alliphatic } \\
v \mathrm{C}=\mathrm{O} \text { (urea) } \\
v \mathrm{C}-\mathrm{N} \text { (urea) } \\
v \mathrm{C}-\mathrm{O} \text { (ester) } \\
\delta \mathrm{C}-\mathrm{C} \text { (ester) }\end{array}$ \\
\hline GAF & $\begin{array}{c}3670-3110 \\
3080-2700 \\
2950-2891 \\
1780 \\
1599 \\
1250\end{array}$ & $\begin{array}{c}v \mathrm{O}-\mathrm{H} \\
v \mathrm{C}-\mathrm{H} \mathrm{sp}^{3} \text { carbon and aromatric } \\
v \mathrm{C}-\mathrm{H} \text { aliphatic } \\
v \mathrm{C}=\mathrm{O} \\
v \mathrm{C}=\mathrm{C} \\
\delta \mathrm{C}-\mathrm{C}(=\mathrm{O})-\mathrm{O} \text { esterified phatalic acid }\end{array}$ \\
\hline GU & $\begin{array}{c}3344 \\
2935 \\
1735 \\
1600-1530 \\
1490-1220\end{array}$ & $\begin{array}{c}v \mathrm{O}-\mathrm{H} \text { and } \mathrm{N}-\mathrm{H} \\
v \mathrm{C}-\mathrm{H} \mathrm{sp} \mathrm{s}^{3} \text { carbon } \\
v \mathrm{C}=\mathrm{O} \\
\delta \mathrm{N}-\mathrm{H} \\
v \mathrm{C}-\mathrm{N}\end{array}$ \\
\hline$\overline{\text { GUF }}$ & $\begin{array}{c}3346 \\
2935 \\
1722 \\
1600-1530 \\
1490-1170 \\
1150-940 \\
\end{array}$ & $\begin{array}{c}v \text { O-H } \\
v \mathrm{C}-\mathrm{H} \mathrm{sp} \text { sarbon }^{3} \text { car } \\
v \text { C=O } \\
\delta \mathrm{N}-\mathrm{H} \\
v \mathrm{C}-\mathrm{N} \\
v \mathrm{C}-\mathrm{O}\end{array}$ \\
\hline GF & $\begin{array}{l}3600-3030 \\
2990-2800 \\
1750-1570 \\
1500-1140 \\
1100-1000\end{array}$ &  \\
\hline
\end{tabular}

and 7.74 were attributed to hydrogen from aromatic ring. The ${ }^{13} \mathrm{C}$ NMR spectrum of GAF presents signals at 63.5 and 72.9 that are attributed to carbons of glycerol. Besides that, the spectrum presents signals at 129.3, 130.1, 136.4 and 175.9, attributed to carbons of aromatic ring and carbonyl. The chemical shifts found to the others resins obtained in this study are showed in Table 3.

The analysis of data taken from the mass spectrum using the software Origin allowed the determination of the weight average molecular weight $(\mathrm{Mw})$, number average molecular weight (Mn) and polydispersity (DPI). The results can be seen in Table 4. The values of Mw and PDI were lower than those found by Stumbo and Bruchmann. ${ }^{19}$ MALDI-TOF spectrum of GAF and GUF resins are shown in Figure 2. It could make a size estimate of the resins chain from the Mw and GAF resin is approximately 15 monomers whereas the monomer is $74 \mathrm{Da}$ per unit, ant they may correspond to a fragment from the glycerin. The GUF resin is approximately 10 monomers, also with 74 Da per 

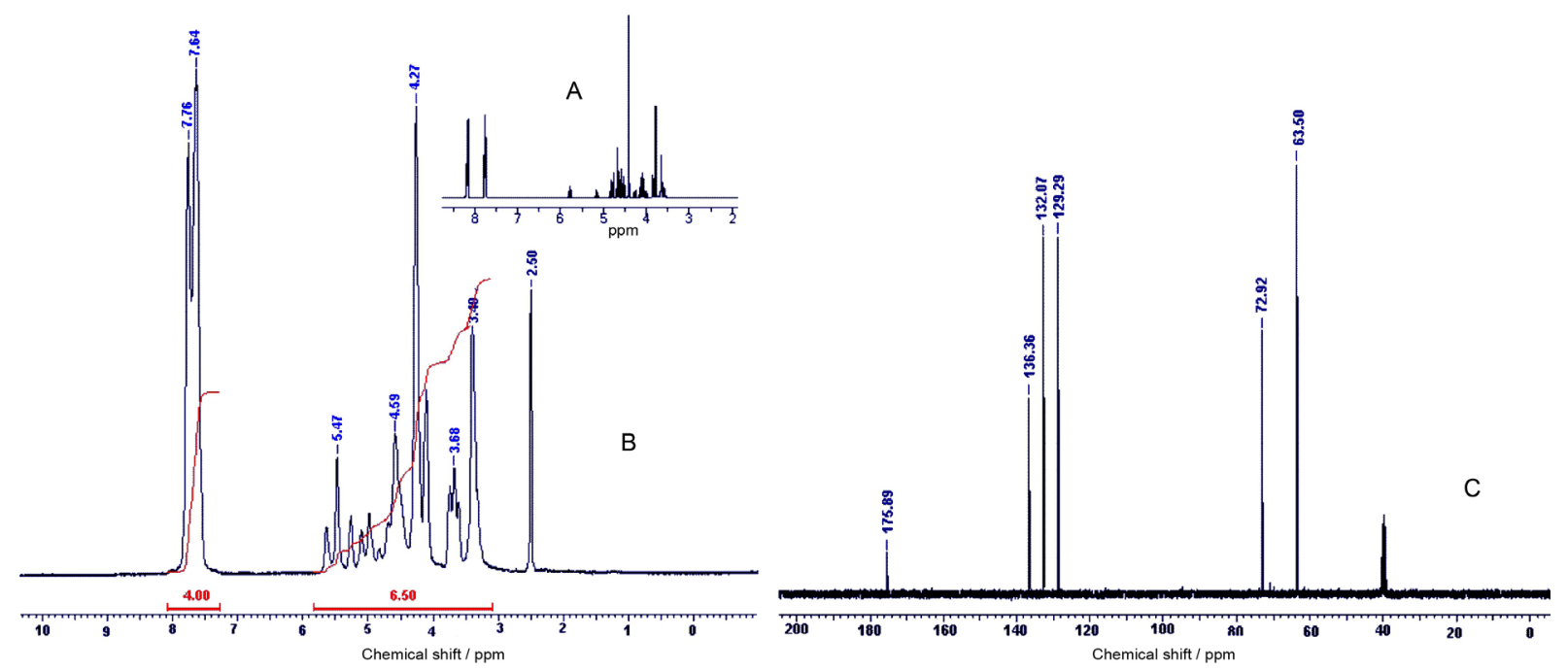

Figure 1. The ${ }^{1} \mathrm{H}$ NMR simulate spectrum (A), ${ }^{1} \mathrm{H}$ NMR real spectrum (B), ${ }^{13} \mathrm{C}$ NMR real spectrum (C) of the resin GAF.

Table 3. NMR results

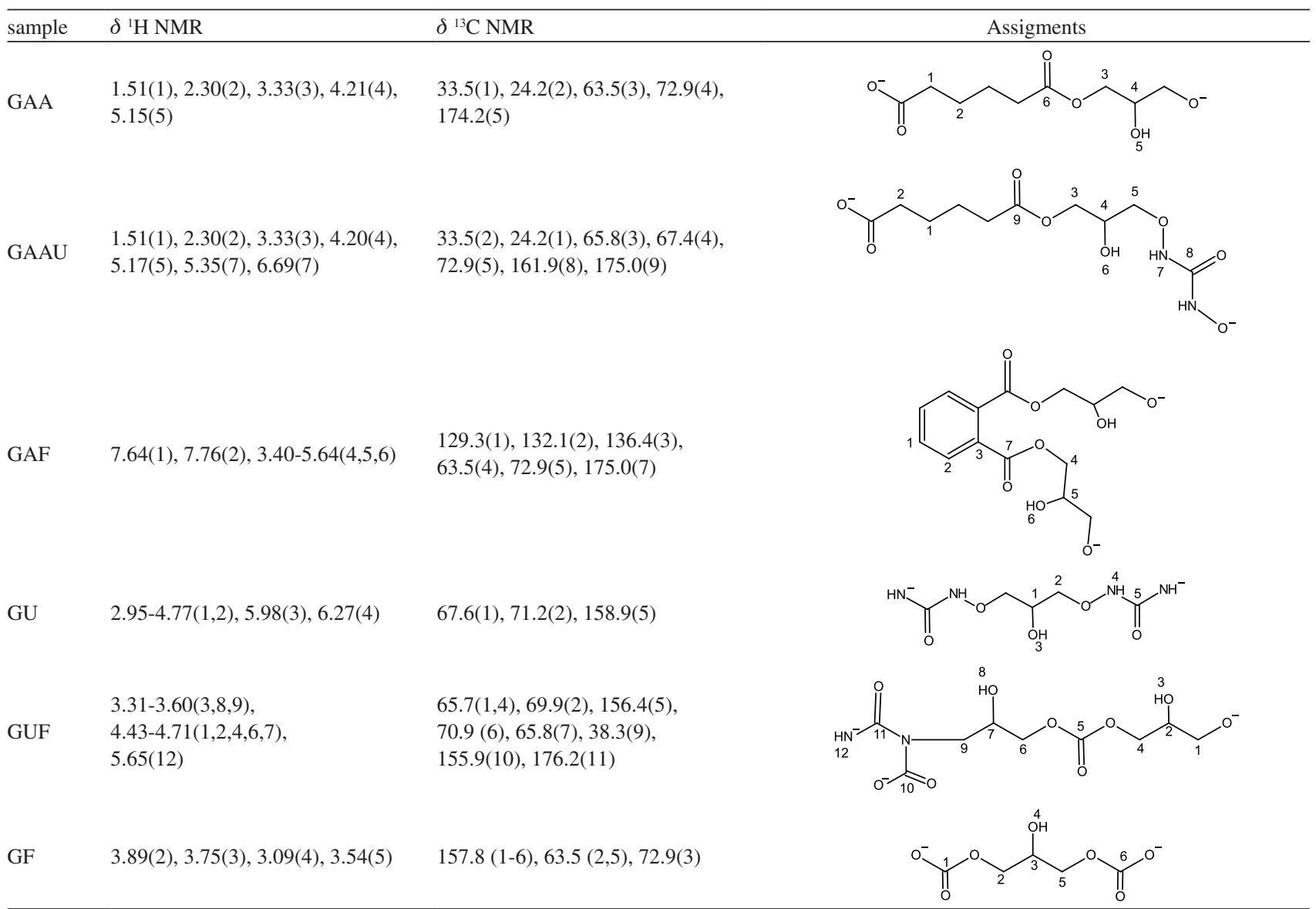

unit. We observed that all the resins are oligomers, and have an average molecular weight below $10,000 \mathrm{~g} \mathrm{~mol}^{-1}$. It was possible through the results of analysis of spectra obtained by MALDI-TOF realize that the average lengths of chains synthesized resins are more regularly when they are formed from dicarboxylic acids.
The average number of the molecular weights determined from GPC for resins studied in this work is showed in Table 4. As observed by MALDI-TOF, all the resins are oligomers and lie in the range of 1800-2800 Da, and the polydispersity indexes in the range of 1.3 to 1.8. The Mn values determined by the GPC method 

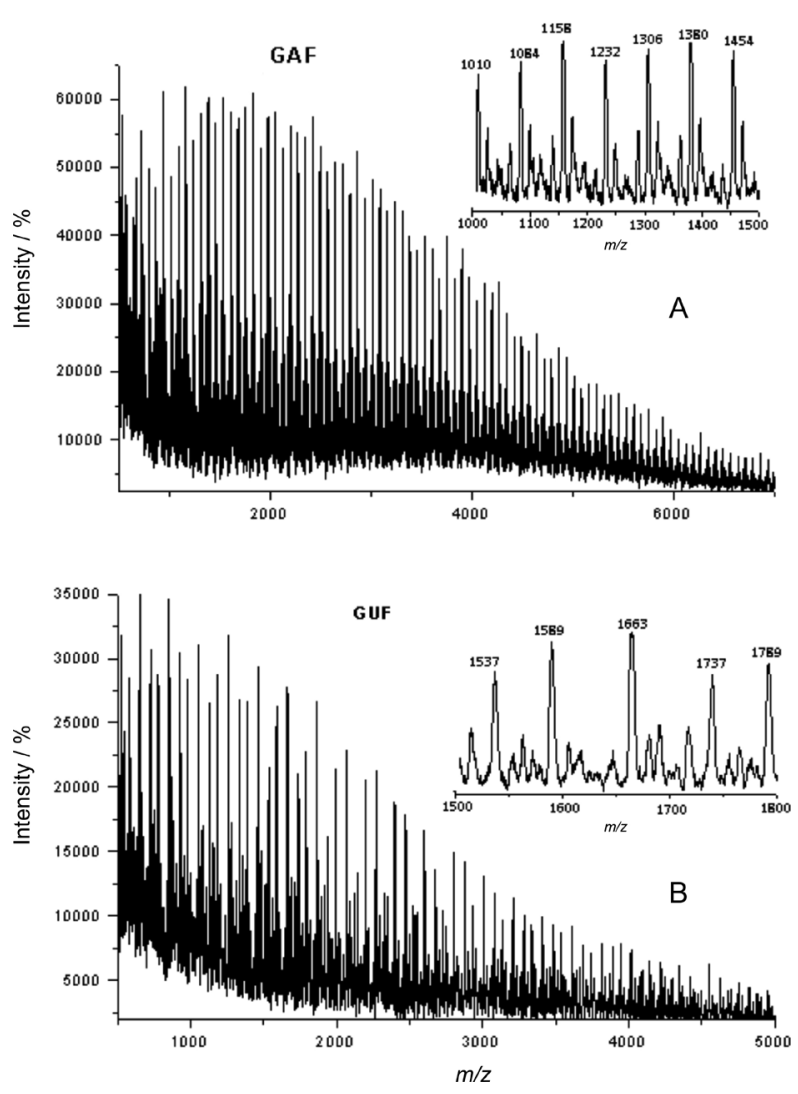

Figure 2. MALDI-TOF spectra of resins (A) GAF and (B) GUF.

differ by $0.05-0.15 \%$ from those determined by MALDI TOF experiments. Thus, these results are very near and showed that the method using results obtained by MALDI-TOF and calculated by Origin software could be used to calculate the molecular weights of resin.

The results of TGA and DSC curves from resins can be divided into two classes, one comprising the resins GAA, GAAU and GAF ( $1^{\text {st }}$ class) and the other comprising the resins GU, and GF GUF ( $2^{\text {nd }}$ class). The first class present a profile as showed in Figure 3, curves with one step of mass loss and the DSC curves present one step with an endothermic peak. The endothermic peak is correlated to the following temperatures and mass loss, GAA $380.61^{\circ} \mathrm{C}$ (96\%), GAAU $425.71{ }^{\circ} \mathrm{C}(95 \%)$, and GAF $377.63^{\circ} \mathrm{C}(97 \%)$.
Those results can be compared with Zorba et al.,$^{22}$ in which the decomposition of the resins occurred at $379,385^{\circ}$ and $412{ }^{\circ} \mathrm{C}$. A small peak below $100{ }^{\circ} \mathrm{C}$ was attributed to small molecules as water, ${ }^{23}$ this peak corresponds to about $1 \%$ of loss mass. When the TGA curves from GAA and GAAU we can observe that temperature of resin degradation increases, being attributed to addition of urea to resin.



Figure 3. TGA, DTA and DSC curves of GAA resin.

The second class of resins that comprehends glycerol, urea and formaldehyde showed two steps of degradation in TGA and DSC curves with endothermic peaks. An example of profile is showed in Figure 4. The first step is correlated to the following temperatures and mass loss:



Figure 4. TGA, DTA and DSC curve of GUF resin.

Table 4. Weight average molecular weight (Mw), number average molecular weight (Mn) and polydispersity index (DPI) of resins investigated in this work

\begin{tabular}{|c|c|c|c|c|c|c|}
\hline$\underline{\text { Resin }}$ & $\mathrm{M}_{\mathrm{w}} /\left(\mathrm{g} \mathrm{mol}^{-1}\right)^{\mathrm{a}}$ & $\mathrm{M}_{\mathrm{n}} /\left(\mathrm{g} \mathrm{mol}^{-1}\right)^{\mathrm{a}}$ & $\mathrm{DPI}^{\mathrm{a}}$ & $\mathrm{M}_{\mathrm{w}} /\left(\mathrm{g} \mathrm{mol}^{-1}\right)^{\mathrm{b}}$ & $\mathrm{M}_{\mathrm{n}} /\left(\mathrm{g} \mathrm{mol}^{-1}\right)^{\mathrm{b}}$ & $\mathrm{DPI}^{\mathrm{b}}$ \\
\hline GAA & 4.966 & 3.378 & 1.47 & 5.143 & 3.127 & 1.64 \\
\hline GAAU & 3.610 & 2.170 & 1.66 & 4.375 & 2.697 & 1.62 \\
\hline GAF & 4.134 & 2.730 & 1.51 & 4.603 & 3.012 & 1.53 \\
\hline GU & 2.183 & 1.734 & 1.26 & 2.303 & 1.964 & 1.17 \\
\hline GUF & 2.234 & 1.709 & 1.31 & 2.080 & 1.302 & 1.59 \\
\hline $\mathrm{GF}$ & 3.165 & 2.212 & 1.43 & 3.300 & 2.375 & 1.39 \\
\hline
\end{tabular}

${ }^{a}$ Molecular weight determined from MALDI-TOF using Origin software; ${ }^{\mathrm{b}}$ molecular weight determined from GPC. 
GU, $200-450{ }^{\circ} \mathrm{C}(34$ and $58.7 \%)$; GUF, $200-400{ }^{\circ} \mathrm{C}(23$ and $71.5 \%)$; GF, $180-280{ }^{\circ} \mathrm{C}(88$ and $11 \%)$.

\section{Conclusions}

The polymerization between glycerol, bi-functional and mono-functional organic groups proved to be an efficient method for the production of new polymers. The NMR and MALDI-TOF techniques allowed to identify structures and molecular weights of the resins studied in this work. The resins are made all within the class of oligomers. TGA and DSC results suggested that the $1^{\text {st }}$ class of resins has good thermal stability (up to $350^{\circ} \mathrm{C}$ ) and the $2^{\text {nd }}$ one has an intermediate thermal stability (up to $200{ }^{\circ} \mathrm{C}$ ).

The use of these materials for the development of composites derived from natural fibers will be considered and is going to be a topic of research in our research group soon.

\section{Acknowledgments}

The authors would like to thank the Brazilian agencies, CAPES (Coordenação de Aperfeiçoamento de Pessoal de Nível Superior), CNPq (Conselho Nacional de Desenvolvimento Científico e Tecnológico), FINEP (Financiadora de Estudos e Projetos) and FAPEPI (Fundação de Amparo à Pesquisa do Estado do Piauí) for their financial suporte. We would like to thank Dr. Donald J. Darensbourg and Texas A\&M University for the results from MALDI-TOF and GPC.

\section{References}

1. Chandra, R.; Rustgi, R.; Polym. Degrad. Stab. 1997, 56, 185.

2. Vichi, F. M.; Mansor, M. T. C.; Quím. Nova 2009, 32, 757.

3. Galembeck, F.; Barbosa, C. A. S.; Sousa, R.; Quím. Nova 2009, 32,571 .

4. Mota, C. J. A.; Silva, C. X. A.; Gonçalves, V. L. C.; Quím. Nova 2009, 32, 639.
5. Dabdoub, M. J.; Bronzel, J. L.; Rampim, M. A.; Quím. Nova 2009, 32, 776.

6. Medeiros, M. A.; Araujo, M. H.; Augusti, R.; Oliveira, L. C. A.; Lago, R. M.; J. Braz. Chem. Soc. 2009, $20,1667$.

7. Gonçalves, V. L. C.; Pinto, B. P.; Silva, J. C.; Mota, C. J. A.; Catal. Today 2008, 133-135, 673.

8. Zhou, C.-H.; Beltramini, J. N.; Fan, Y.-X.; Lu, G. Q. M.; Chem. Soc. Rev. 2008, 37, 527.

9. Adhikari, S.; Fernando, S.; Haryanto, A.; Energy Fuels 2007, 21, 2306.

10. Adhikari, S.; Fernando, S.; Haryanto, A.; Catal. Today 2007, 129, 355.

11. Byrd, A. J.; Pant, K. K.; Gupta, R. B.; Fuel 2008, 87, 2956.

12. Medeiros, M. A.; Rezende, J. C.; Lago, M. R.; Polímeros 2010, 20, 188.

13. Cardona, F.; Ku, H.; Chouzenoux L. J.; J. Reinf. Plast. Compos. 2010, 29, 3543.

14. Guimaraes, D. H.; Brioude, M. M.; Fiuza, R. P.; Prado, L. A. S. A.; Boaventura, J. S.; Jose, N. M.; Mater. Res. 2007, $10,257$.

15. Bucio, E.; La-Estevez, J. C. I.; Ruiz-Trevino, F. A.; AcostaHuerta, A.; Polym. Bull. 2006, 56, 163.

16. Roffael, E.; Schneider, A.; Holz Roh-Werkst. 1983, 1, 221.

17. Schneider, A.; Roffael, E.; May, H. A.; Holz Roh-Werkst. 1982, 40, 339.

18. Eleotério, J. R.; Tomazello Filho, M.; Bortoletto Jr., G.; Ciência Florestal 2000, 10, 75.

19. Stumble, J. F.; Bruchaman, B.; Macromol. Rapid Commun. 2004, 25, 921.

20. Garcia, E.; Laca, M.; Perez, E.; Garrido, A.; Peinado, J.; Energy Fuels 2008, 22, 4274.

21. Rokicki, G.; Rakoczy, P.; Parzuchowski, P.; Sobiecki, M.; Green Chem. 2005, 7, 529.

22. Zorba, T.; Chrissafis, K.; Paraskevopoulos, K. M.; Bikiaris, D. N.; Polym. Degrad. Stab. 2007, 92, 222.

23. Brioude, M. M.; Guimarães, D. H.; Fiuza, R. P.; Prado, L. A. S. A.; Boaventura, J. S.; Jose, N. M.; Mat. Res. 2007, 10, 335.

Submitted: September 20, 2011

Published online: June 12, 2012 